\title{
Analisis Work Family Conflict dikaitkan Dengan Kepuasan Kerja Perawat Perempuan Rumah Sakit X
}

\author{
Albert Kurniawan Purnomo \\ Program Studi Manajemen Universitas Nurtanio \\ Email: albertsmart9@gmail.com \\ Fotuho Waruwu \\ Program Studi Manajemen Universitas Nurtanio \\ Email:fotuhowaruwu@yahoo.co.id \\ Tria Meisya Aziti \\ Program Studi Manajemen Universitas Nurtanio \\ Email: triameisyaaziti@gmail.com
}

\begin{abstract}
This study aims to analyze the relationship between Work Family Conflict on the satisfaction of hospital nurses in Bandung. This study took 103 samples of female nurses in the hospital using quantitative methods. The data collection tool is a questionnaire. The data analysis technique used was the WarpPLS7.0 program. The results of this study indicate that Work Family Conflict has a significant negative effect on the satisfaction of female hospital nurses. Increasing the p Work Family Conflict will decrease the level of satisfaction.
\end{abstract}

Keywords: Nurses, Work Family Conflict, Satisfaction

\begin{abstract}
Abstrak
Penelitian ini bertujuan untuk menganalisis keterkaitan antara Work Family Conflict pada kepuasan perawat rumah sakit di Bandung. Penelitian ini mengambil 103 sampel perawat perempuan di rumah sakit dengan menggunakan metode kuantitatif. Alat pengumpul data berupa kuesioner. Teknik analisis data yang digunakan dengan menggunakan program WarpPLS7.0. Hasil penelitian ini menunjukkan bahwa Work Family Conflict berpengaruh negatif signifikan terhadap kepuasan perawat perempuan rumah sakit. Peningkatan $p$ Work Family Conflict akan menurunkan tingkat kepuasan.
\end{abstract}

Kata kunci: Perawat, Work Family Conflict, Kepuasan Kerja

\section{Pendahuluan}

Dengan fenomena meningkatnya jumlah perempuan yang bekerja sejalan dengan tingginya tingkat pendidikan. Peran perempuan tak bisa dipandang sebelah mata lagi. Mereka yang berpendidikan tinggi, akan cenderung juga mengejar karier bisnis, pekerjaan, dan professional sesuai bidang keahlian (Handini, dkk, 2014). Adapun alasan perempuan untuk bekerja di luar rumah sangat bervariasi, perempuan termotivasi untuk bekerja karena tiga alasan. Pertama, kebutuhan ekonomi; dimana semakin meningakatnya harga kebutuhan rumah tangga dan juga kebutuhan lain yang mendesak seringkali membuat perempuan merasa kesulitan untuk mengatur keuangan keluarga sehingga memutuskan untuk bekerja. Penghasilan suami yang tidak mencukupi seringkali menjadi alasan bagi perempuan untuk bekerja. Kedua, dengan memiliki pendapatan sendiri, perempuan juga ingin mengurangi ketergantungannya secara ekonomi pada suaminya, terutama untuk membeli barang-barang yang ia sukai. Alasan ketiga adalah untuk memenuhi kebutuhan psikologis, seperti status dan kontak sosial, realisasi potensi, serta hasrat untuk berguna bagi masyarakat. Dengan bekerja, perempuan akan merasa dapat menunjukkan kedudukan sosial serta jaringan pertemanan yang mereka miliki. Peran wanita saat ini semakin diakui sehingga memiliki kesempatan yang sama dengan laki-laki yang dikenal sebagai emansipasi wanita.

Menurut Kamus Besar Bahasa Indonesia dalam Umniyyah (2018) emansipasi wanita adalah proses pelepasan diri para wanita dari kedudukan sosial ekonomi yang rendah atau dari pengekangan hukum 
yang membatasi kemungkinan untuk berkembang dan untuk maju. Hal ini mengubah persepsi masyarakat akan wanita yang hanya bisa melakukan pekerjaan rumah dan mengurus anak. Selain itu, juga memberikan dampak yang positif bagi tenaga kerja wanita yang bekerja karena hak-hak yang diberikan setara dengan tenaga kerja pria. Dengan adanya emansipasi wanita, semakin berkembangnya jaman membuat peran wanita juga semakin berkembang di dunia kerja. Pekerja wanita memiliki konsekuensi baik positif maupun negatif dari peran ganda yang dijalaninya. Selain itu, juga memiliki tanggung jawab menjadi seorang ibu yang harus mengasuh dan mendidik anaknya dengan baik sekaligus menjadi istri yang harus melayani suami. Dengan adanya peran wanita sebagai pekerja dapat meningkatkan kesejahteraan keluarga karena terdapat dua sumber pendapatan yaitu dari suami dan istri yang bekerja. Hal ini diharapkan dapat memenuhi tuntutan kebutuhan rumah tangga yang semakin lama semakin meningkat. Biaya pendidikan anak juga semakin meningkat sehingga diperlukan pemasukan yang lebih besar yaitu salah satunya dengan cara pasangan suami istri yang bekerja. Namun, tidak menutup kemungkinan bahwa peran istri sebagai pekerja memicu terjadinya konflik antar peran (Junaidi, 2017). Hal tersebut menyebabkan terjadinya kesenjangan pada kedua peran yang dijalani sehingga pelaku peran ganda perlu diperhatikan demi kelangsungan hidupnya yang sejahtera. Peristiwa tersebut dapat disebut dengan work family conflict.

Work family conflict juga terjadi karena pemenuhan kebutuhan pada salah satu peran membuat kesenjangan pada pemenuhan peran yang lainnya. Bagi karyawan perempuan yang sudah berkeluarga tentu saja akan dibutuhkan kepandaian untuk mengimbangi waktu antara keluarga dan pekerjaan. Ketika terjadi ketidakseimbangan peran ganda seorang pekerja perempuan maka tidak menutup kemungkinan akan terjadinya ketidakharmonisan di dalam keluarga yang berdampak pada munculnya konflik pada pekerjaannya. Konflik di dalam pekerjaan tersebut salah satunya dapat ditandai dengan menurunnya kinerja karyawan. Di mana ketika kinerja seorang karyawan menurun maka tidak menutup kemungkinan ketidakharmonisan keluarga semakin bertambah.

Menurut Retnaningrum \& Musadieq (2016), work family conflict dibagi menjadi dua yaitu work interference with family (WIF) dan family interference with work (FIW). WIF merupakan konflik yang terjadi antara peran pada organisasi sebagai karyawan dengan peran pada keluarga sebagai ibu yang selanjutnya waktu dengan keluarga menjadi tersita dikarenakan urusan pekerjaan. Misalnya, seorang wanita pekerja harus mengerjakan tugas pada organisasinya hingga lembur dikantor atau mengurus anak dirumah. Jadi, pemenuhan peran sebagai pekerja dapat mengurangi waktu dengan keluarga. Sedangkan, FIW merupakan konflik yang terjadi antara peran pada keluarga menyebabkan adanya kesenjangan pada peran sebagai karyawan sehingga peran pada keluarga yang mempengaruhi peran pada organisasi. Misalnya, seorang wanita pekerja harus membatalkan agenda rapat bersama atasan dan koleganya dikarenakan anaknya sedang sakit.

Masalah bahkan lebih sering terjadi dalam rumah tangga yang mana ibu rumah tangganya bekerja dengan sistem shift, baik shift pagi, siang bahkan malam dan ini lebih banyak menimpa wanita yang bekerja sebagai perawat di rumah sakit. Berdasarkan hal tersebut, peneliti tertarik untuk meneliti permasalahan yang terjadi dalam rumah tangga khususnya wanita yang bekerja sebagai perawat di salah satu RS X yang berlokasi di kota Bandung Jawa Barat. Rumah sakit menjadi suatu industri yang bergerak dalam bidang jasa pelayanan kesehatan dikarenakan munculnya rumah sakit swasta serta pemodal dari dalam negeri maupun luar negeri. Kualitas Sumber Daya Manusia (SDM) merupakan salah satu aset yang dapat menentukan maju mundurnya suatu organisasi. Sumber daya manusia berasal dari kenyataan bahwa manusia (orang-orang) merupakan elemen yang senantiasa ada di dalam setiap organisasi (Simamora, 2018).

Kepuasan kerja adalah bagaimana persepsi individu terhadap pekerjaannya yang akan menimbulkan penilaian terhadap tempat kerja (RS X), juga perasaan suka atau tidak suka terhadap pekerjaannya. Kepuasan kerja karyawan tersebut dapat diukur melalui kemampuan individu, tugas yang diberikan, pencapaian terhadap prestasi kerja, kesempatan untuk lebih mengembangkan diri dalam pekerjaan, 
hubungan dengan atasan dan rekan kerja, jumlah gaji yang diterima dan jaminan keamanan dalam pekerjaan.

Persaingan antar penyelenggara layanan kesehatan menjadikan meningkatnya jumlah rumah sakit. Persaingan ini tidak hanya terkait dengan bangunan dan sarananya saja, tetapi juga terkait dengan kualifikasi SDM dari staf medis dan staf non medis yang ada di dalamnya. Rumah Sakit merupakan salah satu contoh industri yang bergerak dalam bidang jasa pelayanan kesehatan dan bertanggung jawab terhadap pelayanan kesehatan pasien. Dalam memberikan pelayanan kesehatan kepada pasien dilihat dari baik buruknya kinerja di dalam rumah sakit dapat diukur dari kinerja staf medis dan staf non medis. Salah satu dari staf medis rumah sakit yang langsung berhubungan dengan pasien adalah perawat (Wulandari \& Dwiyanti, 2014).

Berdasarkan latar belakang yang telah diuraikan, maka peneliti tertarik untuk melakukan penelitian di salah satu RS Swasta di kota Bandung dengan topik: "Analisis Work Family Conflict dikaitkan Dengan Kepuasan Kerja Perawat Perempuan Rumah Sakit X”.

\section{Kajian Pustaka}

\subsection{Work family conflict}

Konflik kerja-keluarga secara umum dapat didefinisikan sebagai bentuk konflik peran dimana tuntutan peran dari pekerjaan dan keluarga secara mutual tidak dapat disejajarkan dalam beberapa hal (Kussudyarsana \& Soepartini, 2008 dalam Rantika \& Sunjoyo, 2011).

Work family conflict menurut Frone, el al (2000) dalam Retnaningrum \& Musadieq (2016) menyebutkan work family conflict sebagai bentuk konflik peran dimana tuntutan peran dari pekerjaan dan keluarga tidak dapat disejajarkan. Hal ini biasanya terjadi pada saat seseorang berusaha memenuhi tuntutan peran dalam pekerjaan dan usaha tersebut dipengaruhi oleh kemmpuan orang yang bersangkutan untuk memenuhi tuntutan keluarganya, atau sebaliknya. Work family conflict terjadi ketika tuntutan pekerjaan tidak bisa diseimbangkan sehingga terjadi ketidakharmonisan dengan tuntutan keluarga. Berdasarkan penelitian terdahulu (Retnaningrum \& Musadieq, 2016; Rantika \& Sunjoyo, 2011) membagi konflik kerja-keluarga menjadi 2 (dua) dimensi yaitu:

\section{Work Interfering With The Family (WIF)}

Menurut Kossek dan Ozeki dalam Namasivayam dan Zhao (2006) dalam Rantika \& Sunjoyo (2011) WIF merupakan konflik yang muncul ketika peran pekerjaaan mengganggu peran seseorang dalam keluarga. Contoh WIF adalah ketika seorang perempuan karir yang juga seorang ibu, merasa pekerjaannya sebagai perawat menghalanginya untuk dapat menghabiskan waktu dengan anak-anaknya seperti membantu membimbing anaknya saat mengerjakan pekerjaan rumah.

2. Family Interfering With The Work (FIW)

Menurut Kossek dan Ozeki dalam Namasivayam dan Zhao (2006) dalam Retnaningrum \& Musadieq (2016) FIW merupakan konflik yang muncul ketika peran seseorang dalam keluarga mengganggu peran pekerjaan. Contoh FIW adalah ketika seorang perempuan karier yang merasa pekerjaannya terganggu karena harus mengantar anaknya pergi sekolah.

Work-family conflict merupakan salah satu sumber stres yang tidak dapat dihindarkan dari siapa saja, terutama ibu yang bekerja dan tentunya dapat memengaruhi kehidupan mereka, baik dalam keluarga maupun keluarga. Sebagian besar penelitian telah menemukan hubungan negatif antara Work-family conflict dan kepuasan kerja (Anderson et al., 2002; Boles dan Babin, 1996; Frye dan Breaugh, 2004 dalam Hsu, 2011). Namun, kecuali untuk studi oleh Lambert et al. (2002) dalam Hsu (2011) ada sangat sedikit bukti tentang hubungan antara konflik kerja-keluarga dan kepuasan kerja dalam penelitian pemasyarakatan.

\subsection{Kepuasan Kerja}

Menurut Robbins \& Judge (2019) kepuasan kerja merupakan pernyataan emosional positif yang dinyatakan dari hasil penilaian pekerjaan atau pengalaman kerja seseorang. Kepuasan kerja pada 
praktiknya berdampak banyak bagi kelangsungan organisasi, kepuasan kerja tidak hanya sekedar upaya mengurangi stres / tekanan kerja, tetapi juga dapat membantu meningkatkan performa, mengurangi pergantian anggota organisasi, dan mengurangi absensi (ketidakhadiran).

\subsection{Model Penelitian dan Hipotesis}

Model penelitian dapat digambarkan sebagai berikut:

Gambar 1. Model Penelitian

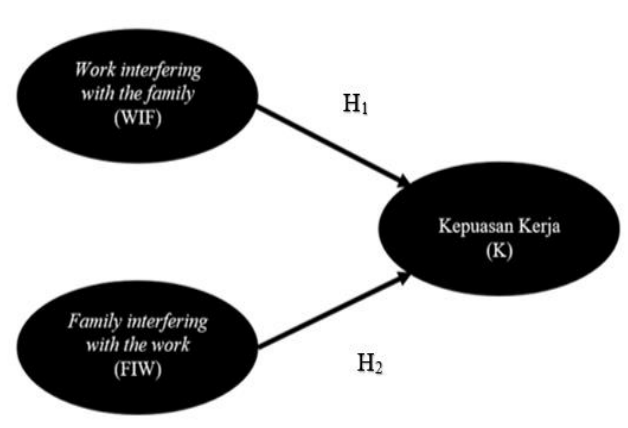

Sumber : Penulis, 2021

Work-family conflict memiliki hubungan negatif dengan kepuasan kerja, hal ini dibuktikan dengan hasil penelitian yang dilakukan oleh berbagai peneliti (Panggabean, 2006; Bacharach dalam Agustina, 2008; Boles dalam Agustina, 2008; Frone et al. dalam Agustina, 2008; Karatepe \& Sokmen, 2006; Kossek \& Ozeki dalam Agustina, 2008; Netemeyer et al. dalam Agustina, 2008; Thomas \& Ganster dalam Agustina, 2008). Mengingat bahwa konflik kerja-keluarga memiliki 2 (dua) dimensi, yaitu Work Interfering with the Family (WIF) dan Family Interfering with the Work (FIW). Berikut ini merupakan penjelasan hubungan antara masing-masing dimensi konflik kerja-keluarga dan kepuasan kerja.

Beberapa penelitian (Anderson et al. dalam Panggabean, 2006; Bacharach dalam Agustina, 2008; Boles dalam Agustina, 2008; Kossek \& Ozeki dalam Agustina, 2008; Thomas \& Ganster dalam Agustina, 2008) menunjukkan bahwa WIF memiliki hubungan negatif dengan kepuasan kerja. Para peneliti lain (Frone et al dalam Agustina, 2008; Karatepe \& Sokmen, 2006; Netemeyer et al dalam Agustina, 2008) menemukan bahwa FIW juga memiliki hubungan negatif dengan kepuasan kerja tetapi hubungannya tidak sekuat WIF.

Kedua dimensi Work-family conflict (WIF dan FIW) memiliki hubungan negatif dengan kepuasan kerja dan penelitian Kossek dan Ozeki (1998) semakin memantapkan bahwa semua dimensi Work-family conflict mengurangi bentuk kepuasan hidup termasuk kepuasan kerja. Hubungan negatif antara konflik kerja-keluarga dan kepuasan kerja dipertegas oleh pernyataan Abbott et al. dalam Agustina (2008) bahwa konflik antara tanggung jawab pekerjaan dan keluarga mengakibatkan rendahnya kepuasaan kerja, meningkatnya absensi, menurunkan motivasi karyawan dan dalam jangka waktu tertentu dapat mengakibatkan turnover karyawan yang meningkat.

Karena penelitian ini berfokus pada hubungan antara konflik kerja-keluarga, maka hipotesis yang diajukan, yaitu:

$\mathrm{H}_{1}$ : Work interfering with the family memengaruhi kepuasan kerja secara negatif.

$\mathrm{H}_{2}$ : Family interfering with the work memengaruhi kepuasan kerja secara negatif. 


\section{Metode Penelitian}

Metode penelitian yang digunakan adalah metode penelitian eksperimen dan survei. Metode penelitian eksperimen merupakan metode penelitian yang digunakan mencari pengaruh tertentu sedangkan metode survei digunakan untuk mendapatkan data dari tempat tertentu yang alamiah, tetapi penelitian melakukan perlakuan dalam pengumpulan data misalnya dengan membagikan kuesioner, test, wawancara terstruktur dan sebagainya (Sugiyono, 2017).

\subsection{Populasi dan Sampel}

Kurniawan (2019) populasi merupakan subjek yang berada pada suatu wilayah dan memenuhi syaratsyarat tertentu berkaitan dengan masalah penelitian. Populasi dalam penelitian ini adalah seluruh perawat perempuan rumah sakit $\mathrm{X}$ berjumlah 123 responden.

Sampel yaitu bagian dari jumlah dan karakteristik yang dimiliki oleh populasi tersebut (Sugiyono, 2017). Sedangkan menurut besarnya sampel dalam penelitian ini ditetapkan dengan rumus Slovin:

$\mathrm{n}=\frac{\mathrm{N}}{1+\mathrm{N}(\mathrm{e})^{2}}$

$\mathrm{n}=\frac{123}{1+123(0,05)^{2}}=94$ responden

Minimal sampel yang harus didapatkan adalah 94 responden, dalam penelitian ini, teknik sampling yang digunakan adalah non probability sampling dengan teknik yang diambil yaitu accidental sampling (Sampel Aksidental), peneliti memperoleh 103 perawat perempuan.

\subsection{Teknik Pengumpulan Data}

Kurniawan (2019) kuesioner adalah suatu alat pengumpul data yang berupa serangkaian pertanyaan tertulis yang diajukan kepada subjek (responden) untuk mendapatkan jawaban secara tertulis.

Kuesioner tersebut berisi daftar pertanyaan operasional yang ditanyakan pada responden terpilih untuk menjawab hipotesis-hipotesis yang dikembangkan sesuai dengan tujuan penelitian. Kuesioner diberikan dalam bentuk daftar pertanyaan beserta jawabannya kepada 103 orang responden guna memperoleh tanggapan mengenai Work Family Conflict dan Kepuasan Kerja Perawat Perempuan Rumah Sakit X.

\subsection{Definisi Operasional Variabel}

Variabel Work Family Conflict memiliki 2 (dua) dimensi yaitu work interfering with the family (WIF) dan family interfering with the work (FIW). Work interfering with the family (WIF) dijabarkan ke dalam 5 (lima) indikator. Family interfering with the work (FIW) 5 (lima) indikator (Retnaningrum \& Musadieq, 2016). Kepuasan kerja (Noeary, dkk, 2020) dapat dijabarkan ke dalam 5 (lima) indikator.

\section{Hasil dan Pembahasan}

Teknik analisis data dalam penelitian ini menggunakan analisis SEM, di dalam penelitian ini terdapat variabel Work Family Conflict, dan variabel Kepuasan.

\subsection{Hasil Analisis \\ Pengujian Model}

Tabel 1. Measurement Models

\begin{tabular}{lll}
\hline Fit Indicates & Recommended Value & Value \\
\hline AFVIF & $\leq 3,3$ & 1,298 \\
GoF & medium $>=0.25$ & 0,278 \\
RSCR & ideally $=1$ & 1,000 \\
SSR & $\geq 0,7$ & 1,000 \\
\hline Sumber: Pengolahan & Data dengan WarpPLS 7.0 (2021)
\end{tabular}


Tabel 2. Hasil Uji Reliabilitas

\begin{tabular}{lll}
\hline Variabel & $\begin{array}{l}\text { Composite } \\
\text { Reliability }\end{array}$ & Cronbach's alpha \\
\hline Work interfering with the family & 0,832 & 0,746 \\
Family interfering with the work & 0,808 & 0,703 \\
Kepuasan Kerja & 0,931 & 0,907 \\
\hline
\end{tabular}

Sumber: Pengolahan Data dengan WarpPLS 7.0 (2021)

Tabel 3. Validitas Loading Factor

\begin{tabular}{|c|c|c|c|}
\hline & Work interfering with the family & $\begin{array}{c}\text { Family interfering with the } \\
\text { work }\end{array}$ & Kepuasan kerja \\
\hline$\overline{\text { WIF } 1}$ & 0,711 & & \\
\hline WIF 2 & 0,763 & & \\
\hline WIF 3 & 0,817 & & \\
\hline WIF 4 & 0,624 & & \\
\hline WIF 5 & 0,600 & & \\
\hline FIW 1 & & 0,643 & \\
\hline FIW 2 & & 0,709 & \\
\hline FIW 3 & & 0,681 & \\
\hline FIW 4 & & 0,622 & \\
\hline FIW 5 & & 0,724 & \\
\hline $\mathrm{K} 1$ & & & 0,884 \\
\hline K 2 & & & 0,850 \\
\hline K 3 & & & 0,905 \\
\hline K 4 & & & 0,809 \\
\hline K 5 & & & 0,821 \\
\hline
\end{tabular}

Sumber: Pengolahan Data dengan WarpPLS 7.0 (2021)

Tabel 4. Validitas Average Variance Extracted (AVE)

\begin{tabular}{lc}
\hline Variabel & AVE \\
\hline Work interfering with the family & 0,501 \\
Family interfering with the work & 0,458 \\
Kepuasan kerja & 0,730 \\
\hline Sumber:Pengolahan
\end{tabular}

Sumber: Pengolahan Data dengan WarpPLS 7.0 (2021)

Analisis model pengukuran dari tabel 1 adalah menggunakan beberapa ukuran yang disesuaikan dengan syarat software WarpPLS 7.0, minimal ada empat (4) ukuran dasar, dan semuanya memenuhi syarat. Tahap berikutnya pada tabel 2 adalah pengujian reliabilitas, memiliki syarat Composite Reliability and Cronbach Alpha > 0,70 (Sholihin \& Ratmono, 2013; Noeary, dkk, 2020), dari hasil pengujian reliabilitas, semua variabel laten memenuhi syarat minimal. Berikutnya pada tabel 3 adalah pengujian analisis faktor, di mana syarat minimal yang dikehendaki harus memiliki nilai pada kisaran 0,40-0,70 (Sholihin \& Ratmono, 2013; Latan \& Ghozali, 2017; Noeary, dkk, 2020) dan semua indikator pernyataan memiliki nilai di atas ketentuan kecuali beberapa item pernyataan kepuasan kerja dan turnover intention ada yang tidak terpenuhi. Syarat berikutnya adalah nilai AVE $>0,50$, dan menurut Huang, Chun Che, et al (2013) AVE di atas nilai 0,40 masih dapat diterima, dengan syarat nilai composite reliability lebih dari 0,60 terlihat pada tabel 4 semua variabel di atas 0,40 dan 0,50.

\subsection{Hasil Pengujian Inner Model}

Pengujian model dengan WarpPLS dimulai dengan menganalisis R square untuk setiap variabel laten dependen. Perubahan nilai R-square berguna untuk menilai variabel laten eksogen tertentu terhadap variabel endogen yang memiliki pengaruh substantif. Tabel 5 menunjukkan hasil estimasi R-Square. 
Tabel 5. Nilai R-Square

\begin{tabular}{|l|l|}
\hline Variabel Dependen & R Square \\
\hline Kepuasan Kerja & 0,137 \\
\hline \multicolumn{2}{|l|}{ Sumber: Pengolahan Data dengan WarpPLS 7.0 (2021) }
\end{tabular}

Hasil koefisien determinasi, besar pengaruh Work Family Conflict terhadap Kepuasan kerja adalah 0,137 atau $13,7 \%$.

Gambar 2. Model Struktural

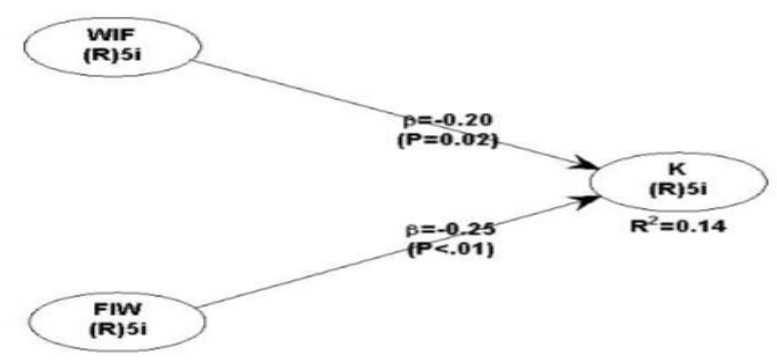

Sumber: Pengolahan Data, (2021)

\subsection{Pengujian Inferesial}

Parameter pengukuran tentang ada tidaknya pengaruh dan signifikan secara parsial antara variabel Work Family Conflict terhadap variabel Kepuasan Kerja diketahui berdasarkan nilai-nilai dengan ketentuan sebagai berikut:

Tabel 6. Hasil Pengujian Model Persamaan Struktural

\begin{tabular}{llccc}
\hline Hipotesis & Pengaruh & Koefisien & Probabilitas & Kesimpulan \\
\hline $\mathrm{H}_{1}$ & WIF $\rightarrow$ Kepuasan Kerja & $-0,201$ & 0,017 & Diterima \\
$\mathrm{H}_{2}$ & FIW $\rightarrow$ Kepuasan Kerja & $-0,251$ & 0,004 & Diterima \\
\hline
\end{tabular}

Sumber: Pengolahan Data dengan WarpS 7.0 (2021)

\subsection{Pembahasan}

Dari penelitian ini akan dibahas beberapa point berdasarkan hipotesis penelitian:

1. Work interfering with the family berpengaruh negatif signifikan terhadap kepuasan kerja. Hasil pengujian menyatakan bahwa tuntutan pekerjaan sebagai perawat membuat sulit untuk hadir dalam rumah, keluarga atau berbagai tanggung jawab pribadi, selain itu tidak dapat bersantai bersama dengan teman teman. Hal ini membuat tingkat kepuasan menjadi menurun. Penelitian ini sejalan dengan Agustina (2008) bahwa konflik antara tanggung jawab pekerjaan dan keluarga mengakibatkan rendahnya kepuasaan kerja.

2. Family interfering with the work berpengaruh negatif signifikan terhadap kepuasan jerja. Berbagai masalah berupa tuntutan keluarga atau pasangan, mengganggu berbagai aktivitas yang berhubungan dengan pekerjaan sebagai perawat. Selain itu juga ditambah terbeban dengan masalah keluarga mengganggu kemampuan dan pemenuhan atas tugas dan tanggung jawab selaku perawat. Hasil penelitian ini selaras dengan hasil penelitian terdahulu oleh Agustina (2008) menemukan bahwa FIW juga memiliki hubungan negatif dengan kepuasan kerja. Dalam temuan penelitian ini didapatkan besar koefisien family interfering with the work lebih besar pengaruh negatif nya dibandingkan Work interfering with the family terhadap Kepuasan kerja. 


\section{Simpulan}

Berdasarkan hasil penelitian yang diperoleh, maka dapat di peroleh simpulan sebagai berikut:

1. Work interfering with the family berpengaruh negatif dan signifikan terhadap kepuasan kerja.

2. Family interfering with the work berpengaruh negatif dan signifikan terhadap kepuasan kerja.

\section{Daftar Pustaka}

Agustina, L. (2008). Pengaruh work-family conflict terhadap job satisfaction dan turnover intention pada profesi akuntan publik: Studi empiris pada kantor akuntan publik di DKI Jakarta dan Bandung. Jurnal Ilmiah Akuntansi, 7 (2), 100-116.

Handini, dkk. (2014). Hubungan antara Work - Family Conflict dan Keterikatan Kerja pada ibu bekerja. Jurnal NOETIC Psychology Volume 4 Nomor 2, Juli-Desember 2014, pp. 169-180.

$\mathrm{Hsu}, \mathrm{Yu} \mathrm{Ru}$. (2011). Work-family conflict and job satisfaction in stressful working environments The moderating roles of perceived supervisor support and internal locus of control. International Journal of Manpower Vol. 32 No. 2, 2011 pp. 233-248.

Huang, Chun Che, et al. (2013). An Empirical Analysis of the Antecedents and Performance Consequences of Using the Moodle Platform. International Journal of Information and Education Technology, Vol. 3, No. 2, April 2013. DOI: 10.7763/IJIET.2013.V3.267.

Junaidi. H. (2017). Ibu Rumah Tangga: Streotype Perempuan Pengangguran. An Nisa'a: Jurnal Kajian Gender dan Anak Volume 12, Nomor 01, Juni 2017.

Kurniawan. A. (2019). Metode Riset untuk Ekonomi dan Bisnis: Teori, Konsep, dan Praktik Penelitian Bisnis. Bandung: Alfabeta.

Latan, H \& Ghozali, I. (2017). Partial Least Squares (Konsep, Metode, dan Aplikasi Menggunakan Program WarpPLS 5.0). Semarang: Badan Penerbit Universitas Diponegoro.

Noeary, S.A.,Purnomo, A.K., Waruwu, F. (2020). Kepuasan kerja sebagai variabel mediasi pada pengaruh stres kerja terhadap niat keluar. Jurnal Manajemen Maranatha, 20(1), 31-40. https://doi.org/10.28932/jmm.v20i1.2752.

Rantika, R \& Sunjoyo (2011). Pengaruh Konflik Kerja - Keluarga Terhadap Komitmen Organisasional yang dimediasi oleh Kepuasan Kerja pada Profesi Perawat di Rumah Sakit Umum Daerah (RSUD) DR. Moewardi Surakarta. Jurnal Manajemen Teori dan Terapan Tahun 4, No. 2, Agustus 2011 , pp.28-43.

Retnaningrum, A.K. \& Musadieq, M.A. (2016). Pengaruh Work-Family Conlict Terhadap Kepuasan Kerja dan Kinerja (Studi pada perawat wanita RSUD Wonosari Yogyakarta). Jurnal Administrasi Bisnis (JAB)|Vol. 36 No. 1 Juli 2016, pp.72-81.

Robbins, S.P \& Judge, T.A. (2019). Organizational Behavior Eighteenth Edition. United States: Pearson.

Sholihin, M \& Ratmono, D. (2013). Analisis SEM-PLS dengan WarpPLS 3.0 : Untuk Hubungan Nonlinier dalam Penelitian Sosial dan Bisnis. Yogyakarta: Penerbit Andi.

Simamora, H. (2018). Manajemen Sumber Daya Manusia. Yogyakarta: STIEY.

Sugiyono. (2017). Metode Penelitian Kuantitatif, Kualitatif, dan R\&D. Bandung : Alfabeta.

Umniyyah. Z. (2018). Jeritan Perempuan yang Terkungkung Sistem Patriarki dalam Kumpulan Cerita Pendek Akar Pule : Suatu tinjauan Feminisme Radikal. Semiotika Vol. 18, No. 2 pp. 158-167.

Wulandari, D \& Dwiyanti, R. (2014). Hubungan antara Konflik Peran Ganda dengan Stres Kerja pada Perawat Wanita yang Sudah Menikah. PSYCHO IDEA, Tahun 12. No.2, Juli 2014. ISSN 16931076.

\section{Copyright Disclaimer}

Copyright for this article is retained by the author(s), with first publication rights granted to the journal. 